\title{
Lički Osik - Urbanističko-arhitektonsko naslijeđe moderne kao razvojni potencijal turizma
}

\author{
Jasenka Kranjčević \\ Institut za turizam, Zagreb, Hrvatska \\ e-mail: jasenka.kranjcevic@iztzg.hr
}

Izidora Marković

Institut za turizam, Zagreb, Hrvatska

e-mail: izidora.markovic@iztzg.hr

\author{
Nikša Božić \\ Hrvatska sekcija ECOVAST-a, Zagreb, Hrvatska \\ e-mail: niksa.bozic@ecovast.hr
}

SAŽETAK Jedno od glavnih pitanja s kojima se suočavaju gradovi u postindustrijskim društvima jest kako i na koji način, nakon propasti industrije, potaknuti novi društveno-ekonomski i kulturni razvoj. To je pitanje od posebne važnosti u sredinama u kojima je došlo do propasti industrije i koje se suočavaju s brojnim gospodarskim i socijalnim izazovima. U Hrvatskoj to je primjer Ličkog Osika, planski izgrađenog industrijskog grada neposredno nakon Drugoga svjetskog rata.

Kroz istraživanje elemenata urbanističko-arhitektonskog naslijeđa u radu se utvrđuju činitelji lokalnog identiteta Ličkog Osika. S obzirom da prostorni identitet zadire i u osobnu percepciju, provedena je anketa među rezidentima i nerezidentima kako bi se istražila percepcija prostornog identiteta te utvrdili potencijali kulturnog naslijeđa u funkciji razvoja. Posebno se istražuju potencijali urbanističko-arhitektonskog naslijeđa Ličkog Osika za razvoj kulturnog turizma.

Ključne riječi: Lički Osik, urbanističko-arhitektonsko naslijeđe, turistička atrakcija, percepcija identiteta, naslijeđe u funkciji turizma. 


\section{Uvod ${ }^{1}$}

Urbanističko naslijeđe kao dio identiteta prostora i memorija s jedne strane te planovi razvoja i percepcija turističkih atrakcija s druge strane predstavljaju poveznicu između prošlosti, sadašnjosti i budućnosti, odnosno naslijeđa u funkciji razvoja.

Brojna istraživanja potvrđuju da se u turističkoj ponudi sve više implementira kulturno naslijeđe ne samo svjetskog značenja već i onog lokalnog (Catrina, 2015.; Bamert, 2016.). Stoga se na različitim razinama izrađuju dokumenti koji daju veliku važnost materijalnom i nematerijalnom naslijeđu. Pritom na lokalnoj razini sve više jača značaj lokalne zajednice u prepoznavanju i očuvanju naslijeđa te kreiranju turističke ponude.

Gotovo se svi gradovi u postindustrijskim društvima suočavaju s izazovima kako i na koji način nakon propasti industrije potaknuti novi društveno-ekonomski i kulturni razvoj. Jedna od mogućnosti prepoznavanje je turističkog potencijala naslijeđa i njegovo stavljanje u funkciju turizma. Stoga su napori postindustrijskog društva usmjereni na otkrivanje potencijala i prezentiranje zanemarenog materijalnog i nematerijalnog naslijeđa kao i na jačanje odgovornosti pojedinca i zajednice prema naslijeđu (Faro, 2005.).

Kako je Hrvatska zbog svoje povijesti, kulture i prirodnog okruženja okarakterizirana kao zemlja malih gradova prepoznatljivog urbanog identiteta, povijesti i graditeljskog naslijeđa (Apolitika 2013.-2020.:22), u radu se želi istražiti ima li Lički Osik prepoznatljive činitelje urbanističko-arhitektonskog naslijeđa malog grada te percipira li se ono i kako kod rezidenata i nerezidenata.

Nikada u svojoj kratkoj povijesti postojanja, pa tako ni danas, Lički Osik nije imao formalni status samostalnog grada ${ }^{2}$, iako po svojim morfološko-fizionomskim obilježjima te socioekonomskoj strukturi stanovništva i funkcija rada ima obilježja gra$\mathrm{da}^{3}$. Međutim po svojim urbanističkim činiteljima, funkcijama, socioekonomskoj

1 Istraživanje je rađeno u sklopu Znanstvenoistraživačkog projekta 2032-HERU / 2014. - 2018. / Hrvatske zaklade za znanost Urbanizam naslijeđa - Urbanistički i prostorni modeli za oživljavanje i unaprjeđenje kulturnoga naslijeđa, Arhitektonski fakultet Sveučilišta u Zagrebu.

2 Iako je u Hrvatskoj 2016. godine evidentirano ukupno 127 jedinica lokalne samouprave koje imaju status grada, postoje brojna naselja koja nemaju takav status, ali po svojim morfološko-fiziološkim obilježjima te socioekonomskoj strukturi stanovništva i funkcija rada naselja imaju obilježja grada. Takvo poimanje grada temelji se na shvaćanju grada „kao kompaktno sagrađenoga većeg naselja u čijim sekundarnim i tercijarnim djelatnostima radi veći dio aktivnog stanovništva, i to ne samo za vlastite potrebe nego i za potrebe stanovništva šireg prostora. Uz to, grad stanovništvu osigurava i zadovoljavanje životnih potreba kao što su opskrba, promet, obrazovanje, zdravstvena zaštita, dostupnost upravnih i ostalih pravnih usluga i slično (centralne funkcije)" (Ostroški, 2011.:7).

3 Udio nepoljoprivrednih kućanstava te udio zaposlenih mještana koji rade u naselju stanovanja, i to u djelatnostima sekundarnog i tercijarnog sektora. 
strukturi stanovništva i po posebnom statusu koji je imao u odnosu na matično naselje gradske općine (Gospić) Lički Osik pokazuje obilježja samostalnog naselja gradskog karaktera. Radi se o sklopu koji je nastao nedugo nakon Drugoga svjetskog rata i pripada malobrojnoj i specifičnoj grupi planiranih novih gradova u $\mathrm{Hr}-$ vatskoj. Za sada urbanističko-arhitektonsko naslijeđe Ličkog Osika nije evidentirano kao kulturno dobro.

Polazište za ovo istraživanje jest činjenica da je Lički Osik planski izgrađen grad nakon Drugoga svjetskog rata za potrebe vojne industrije. ${ }^{4}$ Društveno-ekonomske promjene kao i ratna razaranja devedesetih godina prošlog stoljeća dovele su do demografskih promjena, a jedina tvornica koja je bila glavni pokretač ekonomskog razvoja prestala je s radom. Stoga se javlja potreba promišljanja o određivanju novih smjernica razvoja, a jedna bi mogla biti temeljena na specifičnom prostornom identitetu.

Na prostoru bivše Jugoslavije (1945. - 1991. godine) izgrađeno je nekoliko novih gradova s ciljem da se u ekonomski zaostale i predominantno ruralne prostore unese koncept industrijalizacije i urbanizacije (Seferagić, 2013.) te da se omogući smještaj i razvoj pojedinih strateških industrija. Uz Lički Osik u Hrvatskoj je planski osmišljena gradnja naselja i luke Ploče (jedno vrijeme Kardeljevo). U Bosni i Hercegovini građeni su Novi Travnik (jedno vrijeme Pucarevo) 5 i Vogošće pored Sarajeva, a u Sloveniji Velenje (jedno vrijeme Titovo Velenje) te Kidričevo pored Ptuja.

Slika 1.

Lički Osik sredinom 1950-ih godina. Pogled na glavni trg

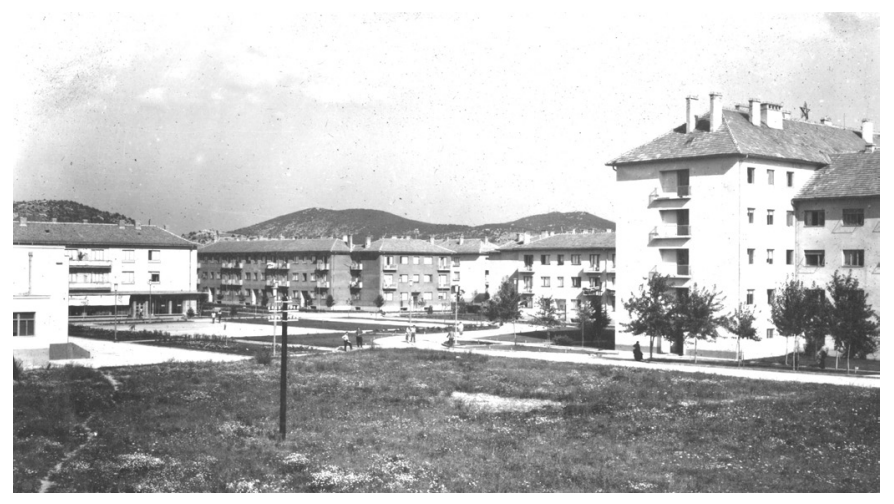

${ }^{4}$ Na urbanističku specifičnost Ličkog Osika pozornost je skrenula udruga Hrvatska sekcija ECOVAST-a kada je 2013. godine pokrenula projekt „Lički Osik - prostorni identitet planiranog grada“. Zaključak projekta bio je da urbanistički i arhitektonski činitelji Ličkog Osika predstavljaju jedinstvene prostorne činitelje, kojih ni današnji stanovnici ni lokalna samouprava nisu svjesni, ali da ih je potrebno istražiti kako bi se naslijeđe moglo staviti u funkciju razvoja.

5 Zanimljivo je da su Lički Osik i Novi Travnik planirani u Urbanističkom institutu SR Hrvatske i vjerojatno su na njihovom planiranju radili isti projektni timovi jer izgrađeni ambijenti i građevine pokazuju dosta sličnosti. 
Slika 2.

Planirani gradovi građeni nakon Drugoga svjetskog rata: Travnik (Bosna i Hercegovina) i Velenje (Slovenija)
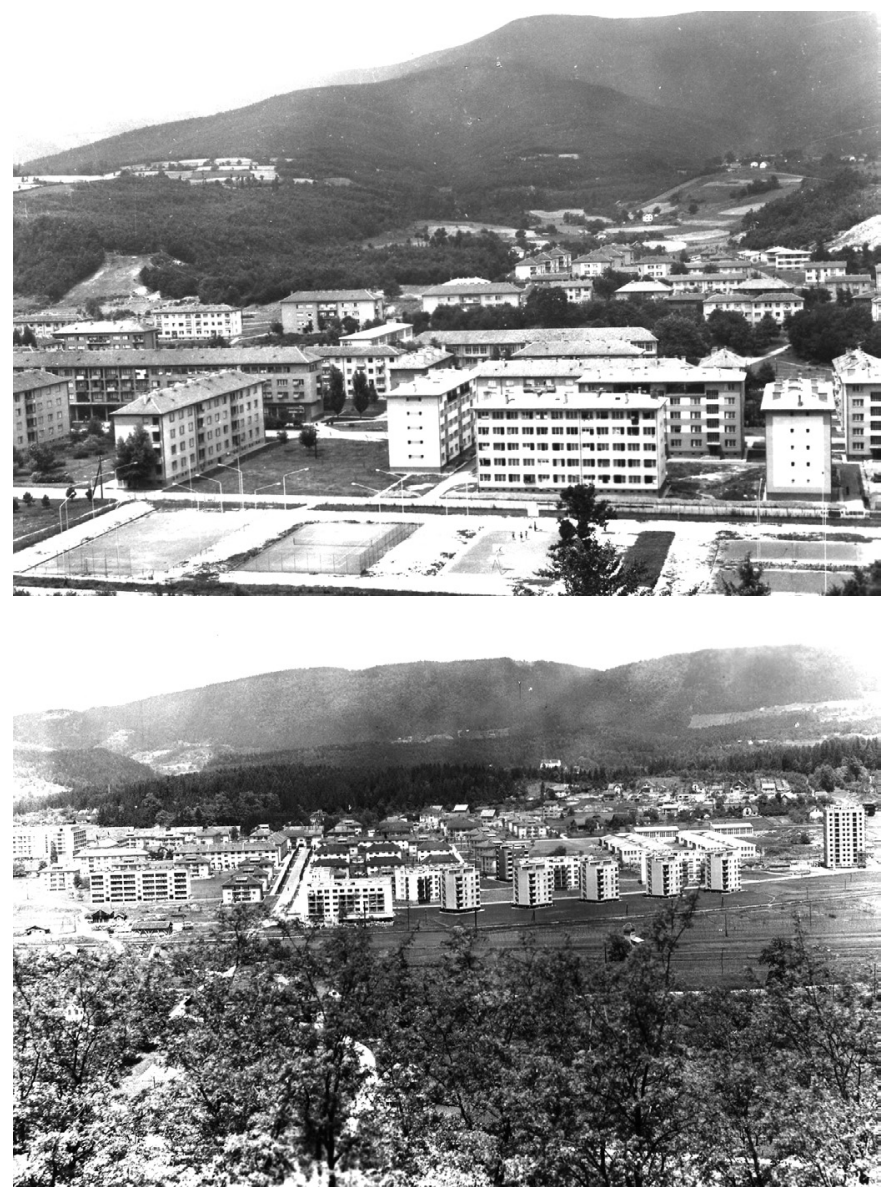

Urbanističko-arhitektonski identitet, kao jedna od odrednica imidža destinacije, iznimno je bitan u percepciji turista ili potencijalnih turista o nekoj destinaciji. Tako da materijalno i nematerijalno naslijeđe kao sastavnice identiteta ponekad svojom jačinom djelovanja mogu definirati glavne činitelje identiteta prostora u percepciji posjetitelja ili potencijalnih posjetitelja. Temeljem prepoznatljivosti pojedinih segmenata prostornog identiteta mogu se kreirati turistički proizvodi s ciljem jačanja turističke ponude u smjeru interesa korisnika/kupaca.

S obzirom da lokalni identiteti prolaze kroz razdoblja izražene atrofije, moguće ih je očuvati samo uz njihovu primjenu u praksi, unutar održivog razvoja gospodarstva (Pejnović, 2010.), pri čemu osobito valja istaknuti održivi turizam. Iznimno je važna uključenost identiteta zajednice u procjenu i planiranje svih oblika turizma te upravljanje njima (Šerić, 2011.), a osobito onih koji u proizvodu uključuju i segmente prostornog identiteta (npr. turizam baziran na naslijeđu). Istovremeno se u literaturi 
često preispituje sposobnost maloga grada da održi svoj urbani format, sa svojim socijalnim i kulturnim posebnostima, pogotovo tamo gdje depopulacija narušava i sam identitet grada (Miletić i sur., 2011.). Stoga je za očuvanje i prezentiranje prostornog identiteta u funkciji turizma bitno postojanje gospodarskih subjekata, koji čine okosnice planiranih gradova druge polovice dvadesetog stoljeća te uključenost svih dionika u proces (Byrd, 2007.). U sredinama u kojima je došlo do potpune propasti industrije glavno je pitanje kako potaknuti novi društveno-ekonomski i kulturni razvoj. S tog polazišta kreće i daljnja analiza Ličkog Osika, kao primjera koji pokazuje: nedovoljno valorizirano naslijeđe, nisku prepoznatljivost prostornog identiteta te brojna neriješena društveno-gospodarska pitanja. Stoga se ovim radom nastoje istražiti činitelji urbanističko-arhitektonskog identiteta Ličkog Osika, percepcija o urbanističkom identitetu te se postavlja pitanje može li urbanističko naslijeđe biti polazište u osmišljavanju turističkih proizvoda i izradi planova razvoja turizma.

\section{Pregled prethodnih istraživanja}

Tema planskih/planiranih industrijskih gradova te mogućnosti njihove revitalizacije učestalija je u svjetskoj i domaćoj literaturi od devedesetih godina prošlog stoljeća, tj. od kada je vidljivije njihovo propadanje kao posljedica deindustrijalizacije u razvijenim zemljama. U znanstvenim radovima naglasak je više postavljen na obnovu urbanističkih struktura (Andrusz i sur., 1996.), odnosno građevinsku rekonstrukciju napuštenih industrijskih zona ili industrijskih kompleksa kroz reinterpretaciju industrijskog naslijeđa ili davanje nove namjene te turizma industrijskog naslijeđa (Föhl, 2014.; Ifko, 2014.; Klempa i sur., 2015.). Istraživanja o percepciji urbanističkog identiteta industrijskih gradova kod stanovnika i mogućih posjetitelja vrlo su malo zastupljena u literaturi.

Istraživanja o industrijskim gradovima druge polovice 20. stoljeća na području bivše Jugoslavije provedena su za gradove Kidričevo, Velenje i Novu Goricu u Sloveniji (Di Battista i Čelik, 2012.), Vareš (Pličanić i Pozder, 2014.; Pličanić i Turkušić, 2014.) i Sarajevo (Smajić i Trožić, 2014.) u Bosni i Hercegovini te Ploče (Curić, 1993.) u Hrvatskoj. S obzirom na industrijalizaciju Istočne Europe u drugoj polovici 20. stoljeća, ističu se i radovi s tog područja koji stavljaju naglasak na industrijsko naslijeđe, primjerice u Slovačkoj (Molnárová, 2014.), Estoniji i Latviji (Ramirez-de-la-Piscina Armendariz, 2014.) te Bugarskoj (Slaev i Nikiforov, 2013.).

Kroz temu urbanog oblikovanja i preoblikovanja industrijskih gradova (Vaetisi, 2011.) danas su sve zastupljenije teme energetske učinkovitosti, održivih materijala kao i zelene arhitekture (Shiraki i sur. 2015.; Kadioglu, 2011.). Brojni ekološki problemi vezani uz rješavanje problema bivših industrijskih/rudarskih zona nastavljaju se na pitanje održivog razvoja gradova (Loures, i Panagopolos, 2007.) koji bi bio u skladu s „Milenijskim razvojnim ciljevima svjetskih gradova“ (UN, 2006.). Upravo zbog nastojanja za održivim razvojem gradova na globalnoj razini sve je veći broj radova koji se bave pojedinim dimenzijama održivog razvoja grada, kao što je urbano planiranje za održive zajednice (McDonald, 2009.). Nadalje, Vranić (2014.) tvrdi da je arhitektura imala (te ima i danas) moć kreativnim se oblikovanjem suprotstaviti 
političkim režimima, te u okvirima svojih mogućnosti učiniti odnos s društvom kompleksnijim i ambivalentnijim.

Identitet gradova i naselja uvjetovan je socijalnom zbiljom, no još više i neposrednije prostorom i njegovim komponentama, pri čemu ukupni urbani ili ruralni krajolik predstavljaju glavne odrednice identiteta mjesta (Fry, 2001.; Stobbelaar i Hendriks, 2004.; Marković i Fuerst-Bjeliš, 2015.). Unatoč stalnim fizičkim promjenama jedinstvenost i višestruka značenja krajolika određujući su elementi za stvaranje prepoznatljivosti i identiteta (Proshansky, 1978.:147). Značajne promjene krajobraza donijelo je i razdoblje iza Drugog svjetskog rata (socijalizam), te je stoga dio radova posebice usmjeren na analizu promjene kulturnih krajobraza u razdoblju socijalizma i postsocijalističke tranzicije te na nastale promjene u prostoru (Holt-Jensen i Raagmaa 2010.; Melluma, 1994.). Među sličnim istraživanjima ističe se analiza promjena u Pridravskoj nizini Osijeka u posljednjih 50 godina (Lončar i Cvitanović, 2012.), gdje se promjene u prostoru utvrđuju daljinskim istraživanjima te povezuju s demografskim promjenama.

\section{Metode rada}

Da bi se mogli utvrdili činitelji urbanističkog identiteta kao i kriteriji za očuvanje te vrste identiteta Ličkog Osika, prvi dio rada odnosi se na istraživanje i sažeti prikaz urbanističko-arhitektonske geneze izgradnje te prepoznavanje činitelja identiteta. Za izradu tog dijela rada korišteni su: stručna i znanstvena literatura, malobrojna građa Državnog arhiva u Gospiću, dostupni prostorni planovi, sačuvane stare razglednice te terenska istraživanja.

Određivanje identiteta osobno je pitanje i nemoguće je dati opću sliku bez sagledavanja subjektivnog pogleda svakog člana zajednice (Penda, 2005.), te je upravo stoga u istraživanju upotrijebljena eksplorativna metoda anketnog upitnika. Anketom su obuhvaćeni nerezidenti, tj. osobe koje nikad nisu živjele u Ličkom Osiku i rezidenti (stanovnici Ličkog Osika, uključivo i nekadašnji stanovnici). Anketiranje nerezidenata provedeno je na slučajnom uzorku populacije Hrvatske (uključujući i strane državljane koji trenutno žive na području RH-a) kako bi se istražile njihove percepcije o prostornom identitetu i potencijalu razvoja Ličkog Osika, pri čemu su anketirana 174 ispitanika. Upitnik za nerezidente sadržavao je deset pitanja, a povrat je iznosio $25 \%$. Istovremeno je provedeno istraživanje rezidenata o percepciji vlastitoga prostornog identiteta i turističkih potencijala Ličkog Osika na uzorku od 111 ispitanika. Upitnik za rezidentne sadržavao je dvanaest pitanja, a povrat je iznosio $58 \%$.

U istraživanju je upotrijebljena metoda neprobabilističkog uzorkovanja (Milas, 2009.), a pitanja su bila otvorenog i zatvorenog tipa. Primijenjene su dvije tehnike prikupljanja podataka: izravnim kontaktom (18\% ispitanih) i internetskim obrascima (82\% ispitanih). Cilj istraživanja bio je usporediti percepcije rezidenata i nerezidenata o identitetu prostora i utvrditi jesu li se razlike u promatranim skupinama ispitanika dogodile slučajno ili postoji značajna statistička razlika kao posljedica razlike u per- 
cepciji identiteta. Ankete su provedene u prosincu 2015. godine. U izračunu je upotrijebljen hi-kvadrat test i Fischerov test u slučajevima $s$ malim brojem pojavljivanja vrijednosti određenog obilježja.

\section{Urbanističko-arhitektonska geneza $\mathrm{i}$ činitelji identiteta}

Ideja o izgradnji novog grada u Lici nastala je neposredno nakon Drugoga svjetskog rata, nakon što je donesena odluka o izgradnji velikog industrijskog kompleksa metaloprerađivačke industrije za potrebe vojno-obrambenog sustava tadašnje Jugoslavije (Kranjčević i Božić, 2012.). Nova tvornica trebala je biti glavni pokretač industrijskog kao i općeg razvoja Like jer se očekivalo da će tvornica pokrenuti i druge djelatnosti koje su u većoj ili manjoj mjeri povezane s njenom osnovnom djelatnošću (Kranjčević i Božić, 2013.). S obzirom da je tvornica trebala zapošljavati oko 1500 radnika, odlučeno je da se uz tvornicu izgradi novi i moderan industrijski grad po mjeri čovjeka (Pavlović, 1956.). ${ }^{6}$ Izrada urbanističkih planova za izgradnju grada povjerena je Urbanističkom institutu SR Hrvatske, koji je tada bio vodeći planerski ured u Hrvatskoj. ${ }^{7}$ U skladu s predviđenim brojem radnika planiran je grad za približno četiri do pet tisuća stanovnika. Planirani broj stanovnika nikada nije realiziran, a prema popisu stanovništva u Ličkom Osiku najviše je zabilježeno nešto više od tri tisuće stanovnika (DZS, 1981.).

Lički Osik planiran je i građen kao proizvod političkog programa socijalizma, koji je između ostalog obuhvaćao i urbanu reformu. Novi grad trebao je predstavljati ogledni primjer grada novoga društvenog uređenja sa svim funkcijama potrebnima za svakodnevni život njegovih stanovnika. Njegovo nastajanje nije bazirano isključivo na elementima ekonomske isplativosti, već na postulatima modernističkog urbanog humanizma. U urbanističko-arhitektonskom smislu radi se o kvalitetnom ostvarenju, s dosljedno provedenim usvojenim prostornim standardima baziranima na poslijeratnom modernističkom i funkcionalističkom planiranju te estetici u arhitekturi.

\footnotetext{
6 Vlada FNR Jugoslavije 11. travnja 1950. godine donijela je odluku o osnivanju poduzeća u izgradnji „Ivan Gošnjak“. Tvornica je pod tim imenom radila do travnja 1954., kada je promijenila naziv u Radna organizacija „Marko Oreškovic“" Lika (skraćeno MOL). Proizvodili su brojne metalne proizvode te imali svoju stručnu školu i istraživački centar. Važan dio proizvodnje odnosio se na vojni program, te je stoga tvornica bila pod direktnom ingerencijom Sekretarijata za obranu.

${ }^{7}$ Usprkos svim naporima originalni urbanistički planovi nisu pronađeni u arhivi Urbanističkog instituta d.d. kao pravnog slijednika Urbanističkog instituta SR Hrvatske. Prezentirani urbanistički planovi preuzeti su iz časopisa Arhitektura (1955.) i Lički kalendar (1956.). Rekonstrukcija nastajanja grada rađena je sakupljanjem podataka iz tadašnjeg dnevnog tiska i stručnih časopisa. Dio geneze grada bilo je moguće rekonstruirati i iz dostupnih urbanističkih planova iz 1980-ih godina. Pretpostavlja se da se izvorni projekt tvornice nalazi u Vojnom arhivu u Beogradu jer je tvornica bila od vojne važnosti za cijelu bivšu državu.
} 


\subsection{Urbanistički koncept $i$ urbanistički planovi}

U kratko vrijeme izrađeni su urbanistički planovi od razine regulacijskih do detaljnih. Prostorni koncept grada zamišljen je (i ostvaren) kao modernistički, koji podrazumijeva zoniranje namjena, funkcionalno i racionalno rješavanje tehničkih sustava te modernistički oblikovni izričaj (slika 3.).

Slika 3.

Regulacijski plan Ličkog Osika iz 1949. godine

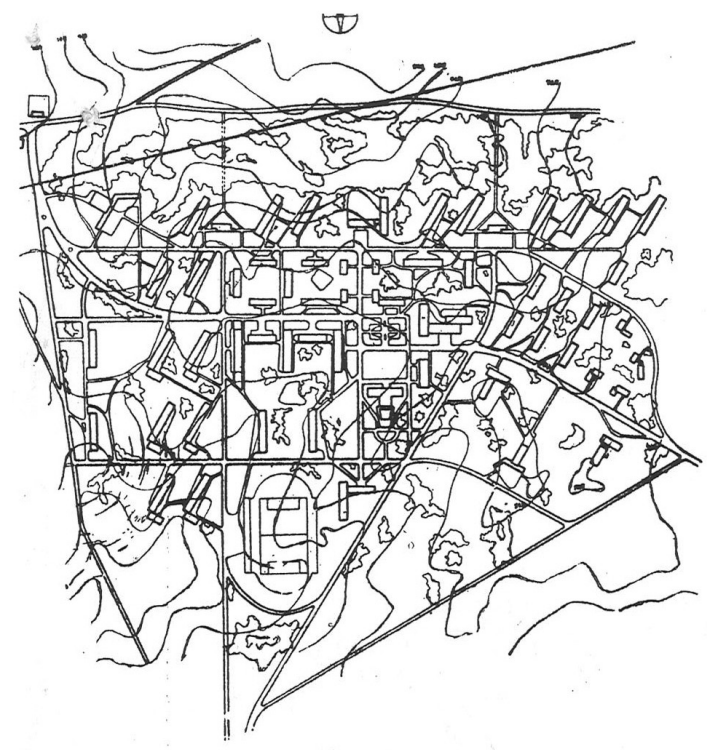

Kako novi grad ne bi bio opterećen tranzitnim prometom, odmaknut je južno od glavne ceste i istočno od željezničke pruge te smješten na udaljenosti od oko $1,5 \mathrm{~km}$ od lokacije na kojoj je sagrađena tvornica. Osnovna načela u planiranju grada bila su tehnička opremljenost, socijalna pravednost i higijenska opremljenost. Pristupna prometnica naselja, koja se odvaja od državne ceste u širokom luku s drvoredom, vodi u naselje, gdje se pretvara u ulicu s obostranim nogostupima, odvojenima od kolnika uskim zelenim pojasevima. Širina ulice odaje dojam reprezentativnosti (slike 4. i 5.).

Radna zona sastojala se od tvorničkog sklopa, koji je zbog svoje specifične namjene izdvojen od grada na udaljenosti $1,5 \mathrm{~km}$. Na površini od otprilike 10,3 ha smješten je tvornički kompleks s upravnom zgradom, proizvodnim pogonom i pratećim prostorima. Zbog tajnosti proizvodnje, ali i zaštite od požara i eksplozije, tvornički je kompleks ograđen visokim zaštitnim zelenilom. Pristup tvornici omogućen je cestom i industrijskim željezničkim kolosijekom. Tvornica je radila još za vrijeme Domovinskog rata (kada taj prostor nije bio pod upravom hrvatskih vlasti). Dosadašnji neuspješni pokušaji osmišljavanja nove proizvodnje na toj lokaciji generiraju brojne ekonomske i socijalne probleme u današnjem Ličkom Osiku. 
Slika 4.

Prostorni smještaj Ličkog Osika u odnosu na postojeće naselje i radnu zonu

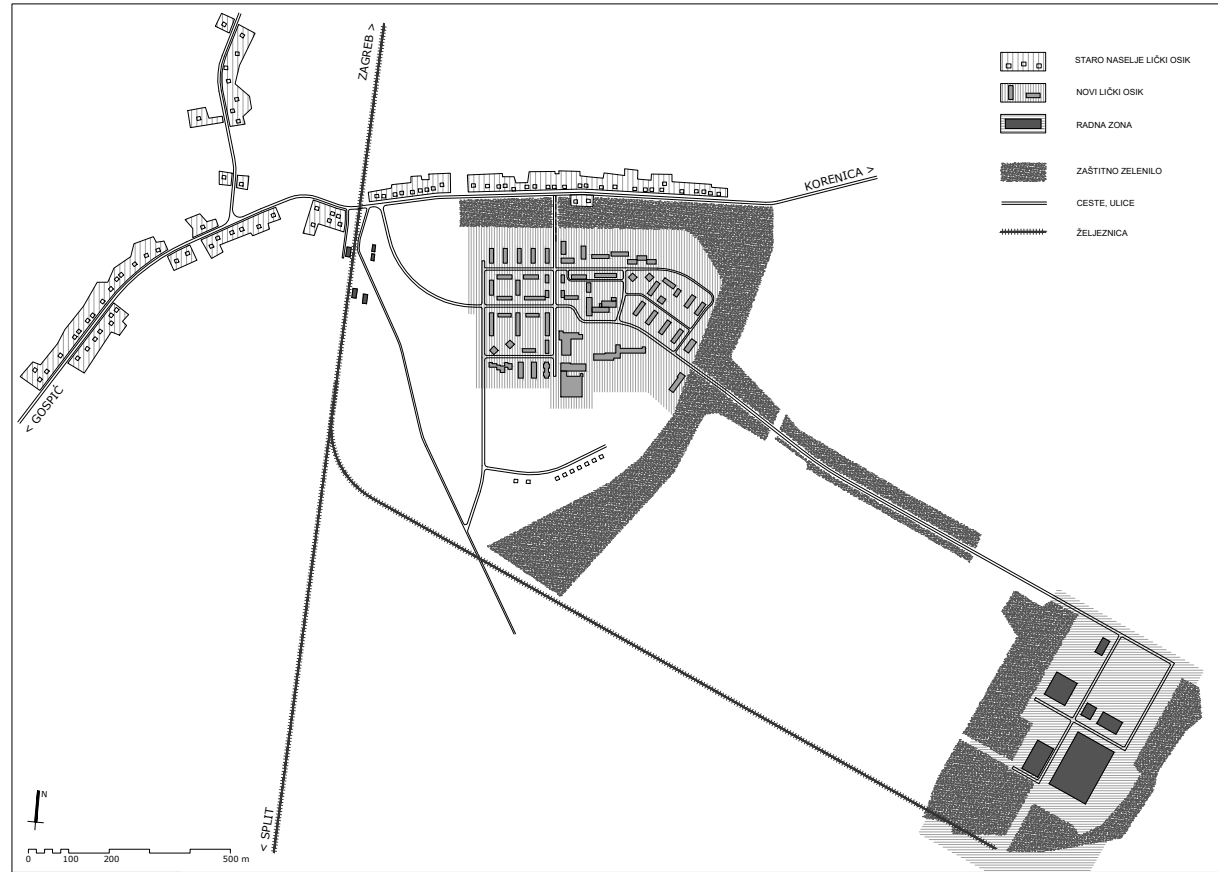

Slika 5.

Funkcionalna shema Ličkog Osika - dispozicija javnih sadržaja i javnih prostora

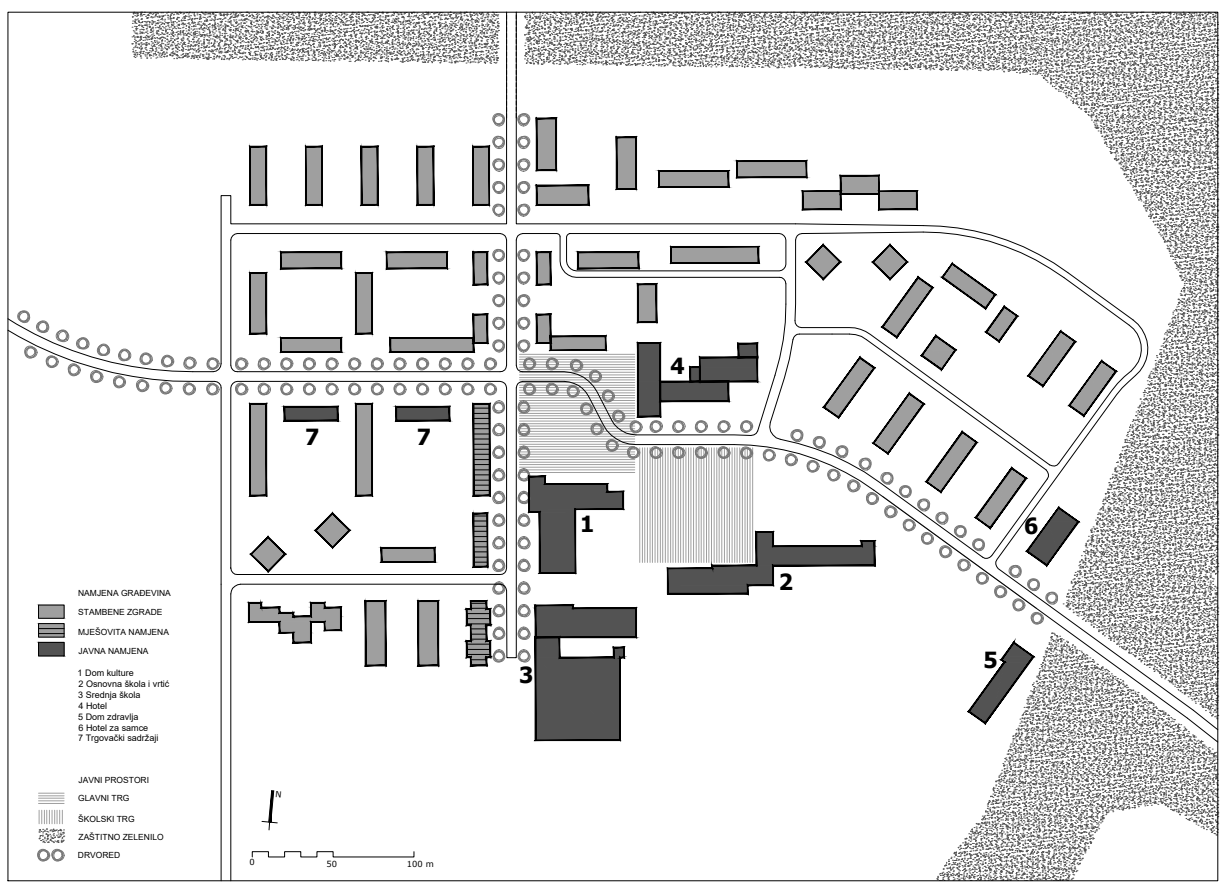


Sukladno modernističkim načelima velika pažnja posvećena je realizaciji javnih, društvenih i uslužnih sadržaja. Na središnjem trgu izgrađen je hotel s 214 ležajeva, koji je bio najveći i najmoderniji hotel u Lici, a istovremeno je bio i najviša zgrada u Lici. Zgrada Doma kulture s knjižnicom, prostorijama za različite društvene aktivnosti te kino dvoranom s cinemaskop tehnikom bila je tada najmodernija u Lici, a smještena je na južnoj strani glavnog trga. Osnovna škola i dječji vrtić sagrađeni su istočno od zgrade Doma kulture, dok je južno od Doma kulture izgrađena velika zgrada srednje strukovne škole, koja je nudila obrazovne programe vezane za potrebe rada u tvornici. Na istočnom rubu grada nalazio se Dom zdravlja s ljekarnom, smješten uz cestu što je vodila do tvornice i na taj način omogućavala paralelne usluge stanovnicima grada te radnicima tvornice. S druge strane te prometnice sagrađen je hotel za samce. Trgovački i uslužni sadržaji naselja bili su smješteni u niskim zgradama s južne strane glavne pristupne prometnice te u prizemljima zgrada sa zapadne strane glavnog gradskog trga. Urbanističkim planom iz 1984. godine u zapadnom dijelu grada bio je planiran gradski servis s autobusnom stanicom, novom željezničkom stanicom i veliko parkiralište, ali taj dio sadržaja nije realiziran.

Slika 6.

Stara fotografija hotela na glavnom trgu Ličkog Osika

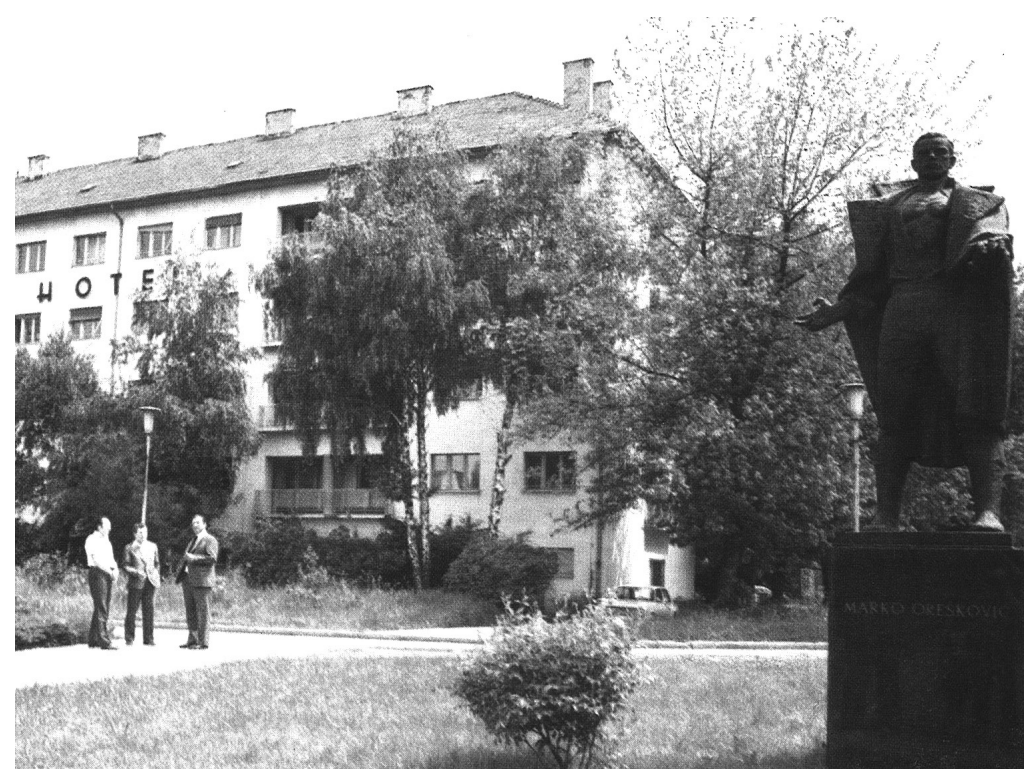

Stambena područja u Ličkom Osiku dijele se na dva tipa: višestambena i individualna. Više od polovice stanovnika trebalo je stanovati u višestambenim zgradama, a ostatak u obiteljskim kućama. Gradilo se brzo, s obzirom na tadašnju opskrbljenost građevinskom mehanizacijom te hladne i duge zime u Lici. U početku su zgrade građene s trima nadzemnim etažama, a kasnije i više (do najviše pet nadzemnih etaža). Iako su zgrade različitih tlocrtnih površina i etaža, većina zgrada koje su izgrađene tijekom 1950-ih i 1960-ih godine imaju ujednačeno oblikovanje (slika 7.). Zbog kontinentalne klime sve stambene zgrade prve faze imaju višestrešna krovišta. 
Slika 7.

Tipovi stambenih zgrada iz rane faze izgradnje Ličkog Osika
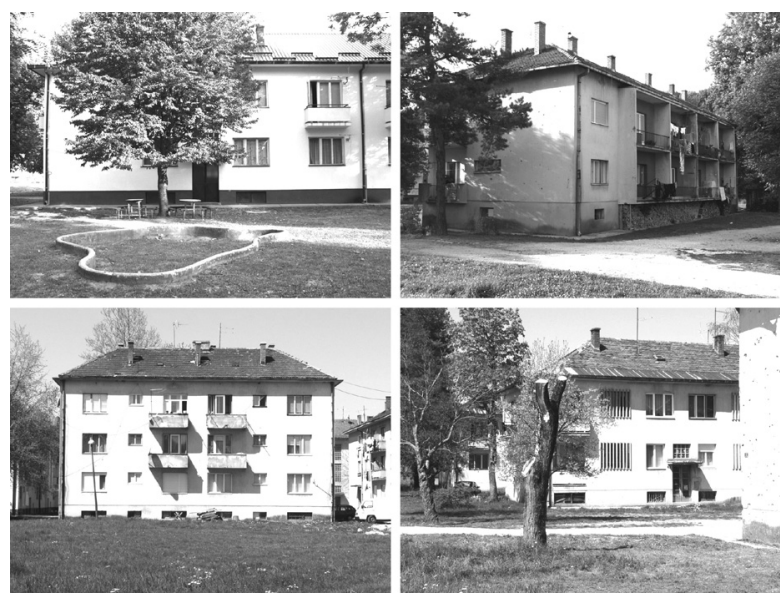

U svim etapama planiranja i izgradnje naselja velika pažnja pridavala se uređenju zelenih površina. Kao što je ranije navedeno, naselje je od industrijske zone zbog zaštite od požara i eksplozije zaštićeno širokim pojasom zasađenog visokog zelenila koje sa sjevera i istoka obrubljuje grad (slika 8.). Zelenilo istodobno ublažava utjecaj dominantnog sjeveroistočnog vjetra. Unutar naselja planirano je $5.000 \mathrm{~m}^{2}$ zelenih površina, dok je izvan naselja zasađeno 15 ha bagrema i topola.

Slika 8.

Sađeno zaštitno zelenilo uz prometnicu koja vodi do radne zone

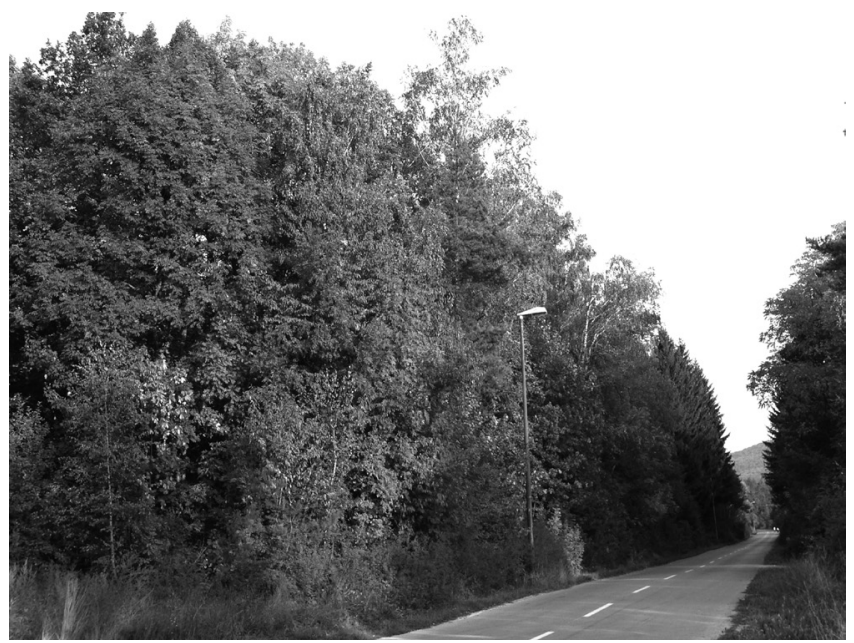

Velika pažnja posvećivala se i planiranju zona sporta i rekreacije. Prema urbanističkom planu veliki stadion planiran je s gledalištem te pripadajućim dvoranama u sjeveroistočnom dijelu naselja, da bi na koncu bio realiziran kao igralište u jugozapadnom dijelu naselja (danas zapušten). Dvorane su izvedene u sklopu školskih zgrada. 


\subsection{Domovinski rat i obnova}

Društveno-ekonomske promjene te Domovinski rat u Hrvatskoj (1991. - 1995. godine) snažno su se odrazili na ekonomske, socijalne i kulturne prilike Ličkog Osika. Za vrijeme Domovinskog rata Lički Osik nije bio pod upravom hrvatskih vlasti i bio je preimenovan u Teslingrad. Nakon ponovne uspostave hrvatske vlasti 1995. godine došlo je do velikih promjena u demografskoj strukturi stanovništva. ${ }^{8}$ Tijekom Domovinskog rata gotovo sve zgrade zadobile su znatna oštećenja, a teren oko grada i tvornički sklop bili su minirani. Tvornica je prestala s radom, a kako je ona bila glavni gospodarski subjekt, u pitanje je dovedeno ekonomsko funkcioniranje grada. Unatoč nekim prijedlozima tvornica nije nastavila s metaloprerađivačkom proizvodnjom.

Obnova nakon Domovinskog rata prvenstveno je bila usmjerena na stambeni fond i razminiranje terena. Obnovljene su zgrada osnovne škole i dječjeg vrtića te zgrada Doma zdravlja.

Većina prostora koji su nekada imali trgovačku i ugostiteljsku namjenu, a nalazili su se u ulici koja vodi do glavnog trga, danas su obnovljeni od većih oštećenja, ali velik dio njih još je uvijek bez namjene, pa naselju daju osjećaj praznine i dezintegracije.

Velika zgrada Doma kulture u potpunosti je bila uništena, a danas je obnovljena samo u manjem (sjevernom) dijelu, gdje su ostvareni prostori za udruge. Veći dio zgrade, uključivo i velika kino dvorana, uklonjen je, i tu je 2010. godine sagrađena stambena zgrada.

Slika 9.

Hotel na glavnom trgu nakon Domovinskog rata (fotografije iz 2011. godine)

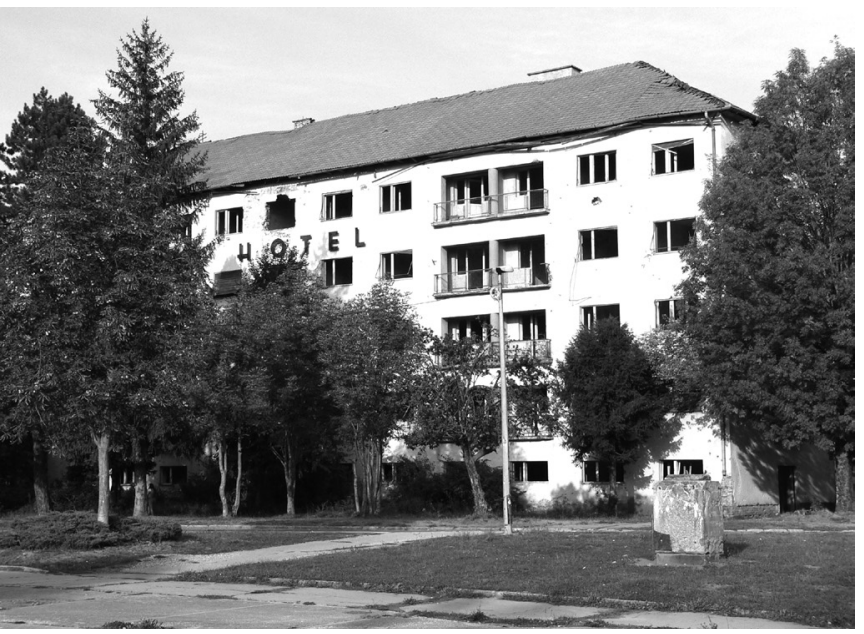

8 Najveći broj stanovnika u Ličkom Osiku evidentiran je 1981. godine, i to 3.045 st., a 2011. evidentirano je 1.892 st. (DZS, 2011.). 


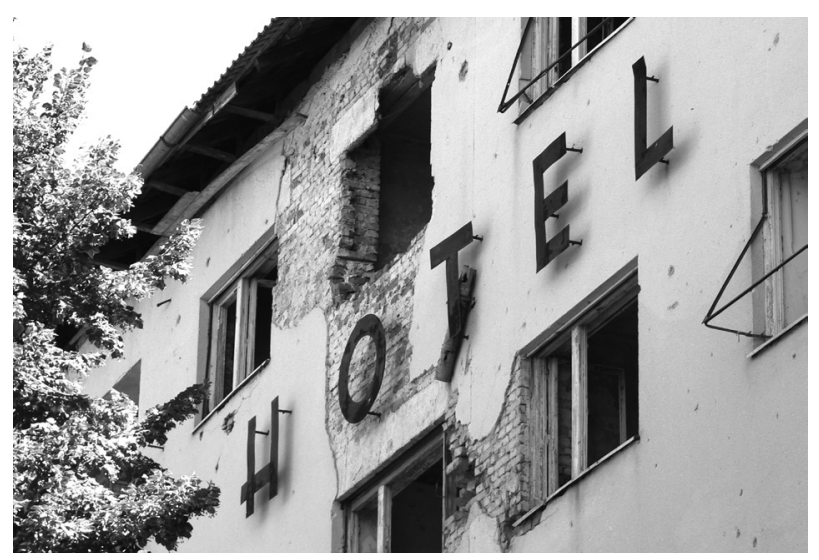

Hotel kao središnja građevina naselja na glavnom trgu pretrpjela je znatna oštećenja i danas još uvijek nije obnovljena, te predstavlja veliki problem naselja (statička stabilnost i sl.). Nekadašnji samački hotel u procesu je dugotrajne rekonstrukcije. Srednja strukovna škola samo je sanirana od osnovnih oštećenja, ali se danas više ne koristi kao škola.

\section{Kriteriji za očuvanje urbanističko-arhitektonskog naslijeđa}

Istraživanjem urbanističkog razvoja potvrđena je glavna hipoteza da Lički Osik ima specifičan urbanističko-arhitektonski identitet razdoblja moderne. Iz urbanističkoarhitektonske strukture vidljivo je da su primijenjena načela modernističkog planiranja, bez težnje za eksperimentima, uz visoku razinu dosljednosti. Postavljeni su razmjerno visoki standardi projektiranja, a tehnologija izgradnje ubrzano se razvijala. Pri tome je naglasak bio stavljen na standardizaciju (koja je omogućavala kontrolu učinkovitosti) te na javne prostore i sadržaje, što je proizlazilo kako iz funkcionalističkih načela projektiranja tako i iz političkog konteksta samoupravnog socijalizma.

Slika 10.

Skladni ambijent stanovanja u zelenilu u Ličkom Osiku - fotografija iz 2011. godine

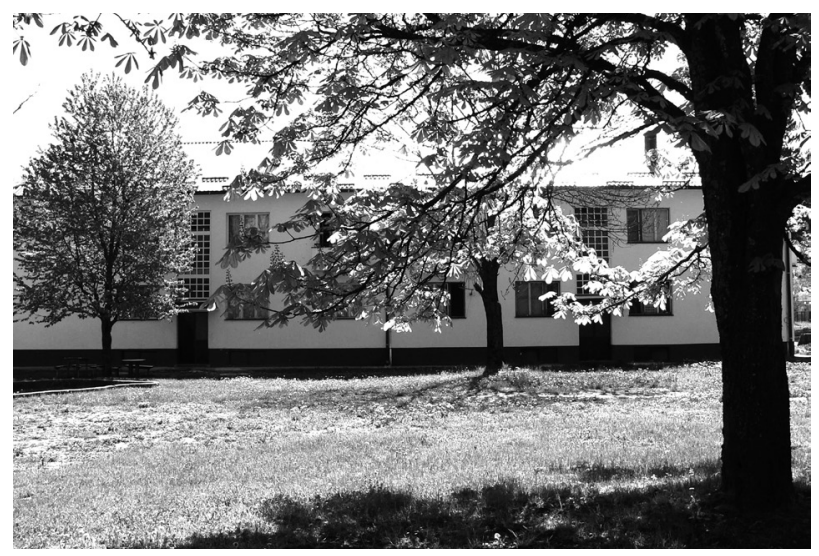


Urbanističko naslijeđe Ličkog Osika specifično je, prepoznatljivo i jedinstveno na prostoru Hrvatske, ali ono još uvijek nije prepoznato od nadležnih službi za zaštitu kulturnih dobara.

Kako se grad već duže vrijeme nalazi u svojevrsnoj ekonomskoj stagnaciji, nije bilo zahtjeva za novom gradnjom, te je sačuvana njegova urbanistička struktura. Dosadašnje građevinske aktivnosti bile su usmjerene na obnovu od ratnih razaranja. Eventualni novi zahvati trebali bi poštivati postojeću urbanističku matricu i građevinsku strukturu i bazirati se na međunarodnim primjerima, gdje se urbanistička matrica kao i građevinska struktura grada promatraju kao cjelina. Svakako da bi se novi zahvati trebali temeljiti na očuvanju i unaprjeđenju prepoznatih činitelja te poštivanju činitelja rijetkosti, izvornosti i jedinstvenosti grada.

\section{Percepcija turističkih potencijala}

Ispitivanje razlika u percepciji Ličkog Osika s obzirom na različita obilježja rezidenata i nerezidenata provedeno je korištenjem hi-kvadrat testa ili Fisherovog testa u slučaju malog broja pojavljivanja pojedine vrijednosti određenog obilježja. Osim testiranja statističke značajnosti, a kako bi se ispitala jačina povezanosti između varijabli, rezultati uključuju i veličinu efekta, odnosno mjeru povezanosti u obliku Phi koeficijenta. Apsolutne vrijednosti Phi koeficijenta iznad 0,50 upućuju na jaku povezanost varijabli, vrijednosti između 0,30 i 0,50 na umjerenu povezanost, između 0,10 i 0,30 na slabu povezanost, a vrijednosti koeficijenta manje od 0,10 na nikakvu ili zanemarivu povezanost između varijabli. Rezultati su analizirani na razini značajnosti od 0,05. Statistička analiza provedena je korištenjem programskog paketa SAS System, verzija 8.2 (SAS Institute Inc., North Carolina, USA).

\subsection{Stanovnici Ličkog Osika}

Lokalno stanovništvo ima vrlo važnu ulogu u pokretanju inicijative i sudjelovanju u razvoju pojedinog naselja, u prvom redu zbog dobrog poznavanja potencijalnih resursa kao temelja za nastanak turističke destinacije. Stoga je suživljenost stanovništva s materijalnim i nematerijalnim naslijeđem, koje u prvom redu čini prostorni/ urbanistički identitet, važna stavka prilikom osmišljavanja razvoja.

Anketirano je 111 ispitanika (5,7\% ukupne populacije Ličkog Osika) koji žive ili su živjeli na području naselja Lički Osik. Većina ispitanika bile su žene (51,8\%), a što se tiče dobne strukture ispitanika većina je bila u dobi od 19 - 59 godina (85,6\%), od 0 - 18 godina je imalo 9,0\% ispitanika, a iznad 60 godina 5,4\% ispitanika. ${ }^{9}$ S obzi-

9 Navedeni podaci ne odgovaraju stvarnoj dobno-spolnoj strukturi Ličkog Osika, no zbog jednostavnosti provedbe ankete putem online upitnika te zbog želje za postizanjem čim većeg broja sudionika ankete, starija je populacija zbog slabijeg korištenja računalima i u manjoj mjeri zastupljena u odgovorima. 
rom na promjene strukture stanovništva koje su se desile tokom devedesetih godina 20. stoljeća i uslijed izražene emigracije i imigracije u istom razdoblju, važno je za napomenuti da 21,5\% ispitanika živi na području Ličkog Osika kraće od 15 godina. Većina ispitanika kao najvažniji prostorni identitet prepoznaje svoj regionalni identitet (Ličanin/Ličanka 59,6\%), potom po značaju slijedi lokalni (Osičanin/Osičanka $27,5 \%$ ), dok nacionalni identitet kao najvažniji ističe tek 12,8\% ispitanika.

Rezultati istraživanja upućuju na značajnu povezanost turističke atraktivnosti Ličkog Osika i percepcije njegovog prostorno-urbanog identiteta među rezidentima $(\mathrm{p}=$ 0,015; Phi $=0,33$. Također, među rezidentima koji smatraju da Lički Osik ima prepoznatljiv prostorno-urbani identitet znatno je veći udio onih koji su sigurni da Lički Osik ima atrakcija koje bi potencijalno mogle privući turiste (35\% prema 9\%).

Nadalje, percepcija turističke atraktivnosti Ličkog Osika značajno je povezana s percepcijom industrijskog i urbanističkog naslijeđa Ličkog Osika kao vrijednog resursa za razvoj inovativnih turističkih ruta $(\mathrm{p}<0,001$; Phi $=0,54)$. Znatno je veći udio onih koji smatraju da Lički Osik ima atrakcija koje bi potencijalno mogle privući turiste (45\% prema 7\%) među rezidentima koji smatraju da je industrijsko i urbanističko naslijeđe Ličkog Osika vrijedan resurs za razvoj inovativnih turističkih ruta. Također, kada ispitanici navode osnovne elemente pozitivne prostorno-urbanističke slike, jasno je da upravo planska izgradnja, promišljenost uređenja i planiranja u doba nastanka grada i njegova cjelovitost predstavljaju osnovne pozitivne elemente (slika 11.).

Slika 11.

Osnovni pozitivni elementi prostorno-urbanističke slike Ličkog Osika

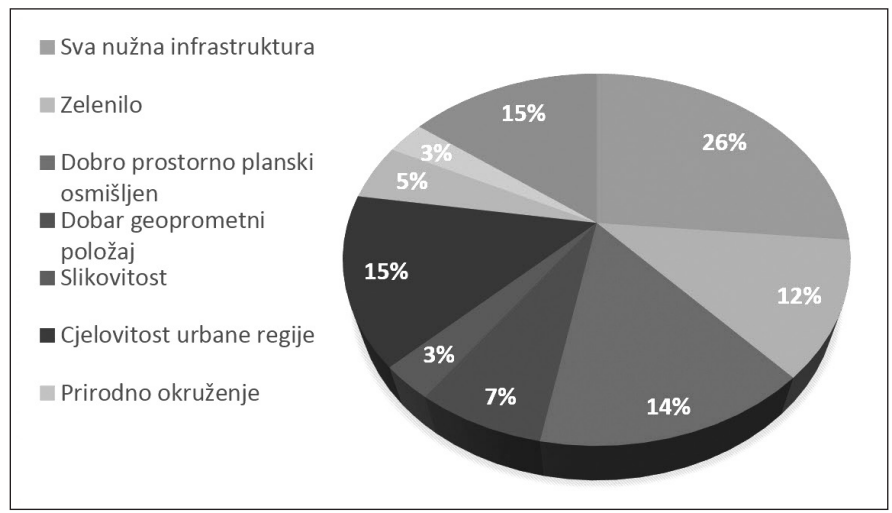

S druge strane domaće je stanovništvo istaknulo i velik broj negativnih prostornourbanističkih slika, koje se u konačnici reflektiraju na sam prostorni identitet mjesta. Tako se kao najčešće istaknuta negativna slika ističe zapuštenost (oronulost, razrušenost i sl.) zgrada, pri čemu je osobito istaknut hotel, koji zbog građevinskog stanja predstavlja opasnost za prolaznike, posebice za djecu. Kao sljedeću negativnu sliku ističu nedostatak parkirnih mjesta i uske ulice te nedovoljno hortikulturno uređenje, 
što je u suprotnosti s prethodno navedenim pozitivnim slikama grada. Iz navedenog se može iščitati dualna percepcija urbanističkih dometa Ličkog Osika, gdje dio stanovnika navedeno smatra najpozitivnijom prostornom slikom, dok je dio stanovnika nezadovoljan funkcionalnošću postojećih urbanih odrednica (slika 12.).

Kada se urbanistički identitet Ličkog Osika razmatra kao osobni identitet stanovnika Ličkog Osika, važno je za istaknuti da ni jedan od osnovnih prostornih elemenata nije prepoznat kao dio osobnog identiteta kod čak 36,2\% ispitanika, dok je 26,7\% ispitanika ustvrdilo da je urbanistički razvoj Ličkog Osika dio njihovog osobnog identiteta, kod podjednakog broja ispitanika dio je osobnog identiteta industrijsko naslijeđe $(18,1 \%)$ i naslijeđe druge polovice 20. stoljeća (19\%).

Slika 12.

Osnovni negativni elementi prostorno-urbanističke slike Ličkog Osika

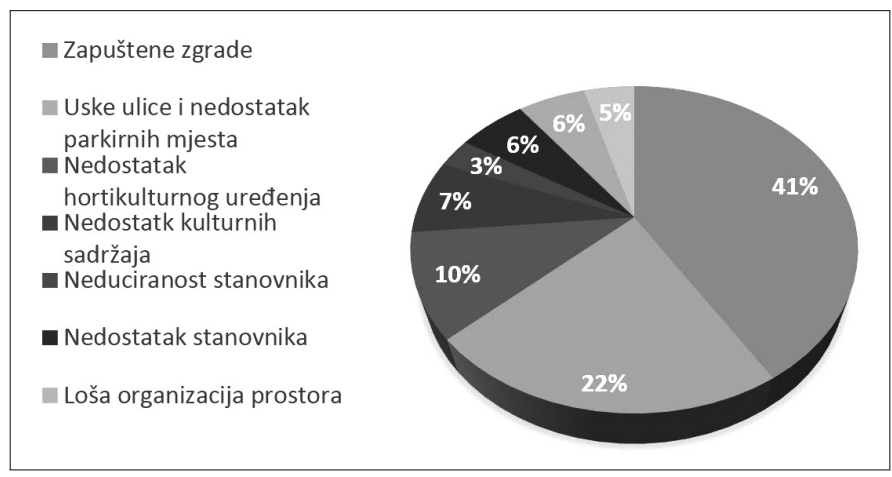

Percepcija potencijala Ličkog Osika kao dijela regionalnih turističkih ruta značajno je povezana s percepcijom industrijskog i urbanističkog naslijeđa Ličkog Osika kao vrijednog resursa za razvoj inovativnih turističkih ruta $(\mathrm{p}=0,002$; Phi $=0,52)$. Rezidenti koji smatraju da Lički Osik ima potencijala da postane dio regionalnih turističkih ruta znatno češće smatraju da je industrijsko i urbanističko naslijeđe Ličkog Osika vrijedan resurs za razvoj inovativnih turističkih ruta. Takvi nalazi daju naslutiti da postoji povezanost između ranije navedene slabe uklopljenosti urbanističkog identiteta u osobni identitet i percepcija mogućnosti razvoja turizma. Međutim među rezidentima koji smatraju da Lički Osik ima potencijal da postane dio regionalnih turističkih ruta znatno je veći udio onih koji smatraju da Lički Osik ima atrakcija koje bi potencijalno mogle privući turiste $(53 \%$ prema $0 \% ; \mathrm{p}=0,003$; Phi $=0,54)$. Pri tome većina ispitanika smatra da je važno povezivanje s Plitvičkim jezerima, rijekom Gackom, Velebitom, Smiljanom te ostalim okolnim ruralnim prostorom, dok je frekvencija isticanja resursa koji se nalaze u samom gradu te su usko povezani s urbanim identitetom vrlo mala (urbanističko naslijeđe planiranog grada - 3 odgovora, hotel - 3 odgovora, industrijsko naslijeđe - 1 odgovor). 


\subsection{Nerezidenti (potencijalni posjetitelji)}

Upitnik za nerezidente sadržavao je pitanja otvorenog i zatvorenog tipa, pri čemu su ispitanici bili zamoljeni da samostalno opišu urbanistički identitet Ličkog Osika s nekoliko ključnih pojmova. Cilj je bio utvrditi koliko je Lički Osik prepoznatljiv onima koji u njemu nikad nisu stanovali, pa čak i među onima koji ga nikad nisu posjetili. U istraživanju je anketirano 174 ispitanika, od čega ih je 58,6\% žena, 41,4\% muškaraca, a u starosnoj strukturi prevladavaju ispitanici srednje dobi. Najveći je udio ispitanika iz Središnje Hrvatske (49,4\%), zatim iz Like (27\%), Istre i Kvarnera $(8,6 \%)$, izvan Hrvatske (8,6\%), (Dalmacije 3,4\%) te Slavonije (2,9\%).

Većina ispitanika nerezidenata (64\%) posjetila je Lički Osik. Percepcija ispitanika glede prostornog identiteta Ličkog Osika značajno je povezana s posjećivanjem, odnosno neposjećivanjem samoga mjesta ( $\mathrm{p}<0,001$; Phi $=0,61)$. Među ispitanicima koji su posjetili Lički Osik njih 60\% smatra da mjesto ima izraženi prostorni identitet, dok isto smatra tek 7\% ispitanika koji nisu posjetili Lički Osik. Među ispitanicima koji ga nisu posjetili čak njih 76\% nije sigurno u izraženost njegovog prostornog identiteta. S obzirom na neupoznatost s identitetom i ponudom Ličkog Osika među ispitanicima koji ga nisu posjetili analiza međuodnosa identiteta i turističkog potencijala Ličkog Osika provedena je na skupu ispitanika koji su već posjetili mjesto. Među onima koji su već posjetili Lički Osik uočena je značajna povezanost percepcije prostornog identiteta mjesta i motiva dolaska ( $\mathrm{p}=0,027$; Phi $=0,26$ ). Među ispitanicima koji smatraju da Lički Osik ima izraženi prostorni identitet znatno je veći udio onih čiji je dolazak motiviran posjećivanjem obitelji ili prijatelja (57\% prema 32\% ispitanika koji smatraju da mjesto nema izražen identitet ili nisu sigurni), odnosno znatno je manji udio onih koji su motivirani turističkim obilaskom (posjet tokom tranzita, razgledavanje, šetnja itd. - 26\% prema 48\%).

U skupu onih koji su već posjetili Lički Osik također je uočena značajna povezanost percepcije prostornog identiteta mjesta i industrijskog i urbanističkog naslijeđa Ličkog Osika kao vrijednog resursa za razvoj inovativnih turističkih ruta ( $\mathrm{p}=0,006$; Phi $=0,31$ ). Među ispitanicima koji smatraju da Lički Osik ima izraženi prostorni identitet znatno je veći udio onih koji industrijsko i urbanističko naslijeđe Ličkog Osika smatraju vrijednim resursom za razvoj inovativnih turističkih ruta (75\% prema 45\%). Također, od dijela ispitanika koji smatraju da postoji izražen prostorni/urbanistički identitet, najviše je ispitanika prepoznalo pozitivne slike koje su isticali i stanovnici Ličkog Osika, kao dio onoga po čemu je grad zapravo i prepoznatljiv. Na prvom mjestu tu je industrija, zatim planska izgradnja, zelenilo, ali i pojedine negativne slike kao zapuštenost, rat i nezaposlenost.

U skupu ispitanika koji su već posjetili Lički Osik uočena je i značajna povezanost percepcije prostornog identiteta mjesta i potencijala da Lički Osik postane dio regionalnih turističkih ruta $(\mathrm{p}=0,017$; Phi $=0,27)$. Među ispitanicima koji smatraju da Lički Osik ima izražen prostorni identitet znatno je veći udio onih koji smatraju da Lički Osik ima potencijala da postane dio regionalnih turističkih ruta ( $72 \%$ prema $45 \%)$. 
Također, među onima koji su već posjetili Lički Osik uočena je značajna povezanost percepcije industrijskog i urbanističkog naslijeđa Ličkog Osika kao vrijednog resursa za razvoj inovativnih turističkih ruta i potencijala da Lički Osik postane dio regionalnih turističkih ruta $(\mathrm{p}<0,001 ; \mathrm{Phi}=0,71)$. Zanimljivo je da je i među ispitanicima koji smatraju da Lički Osik ima potencijal da postane dio regionalnih turističkih ruta znatno veći udio onih koji smatraju da je industrijsko i urbanističko naslijeđe Ličkog Osika vrijedan resurs za razvoj inovativnih turističkih ruta (91\% prema 21\% ispitanika koji ne smatraju da Lički Osik ima potencijal da postane dio regionalnih turističkih ruta).

Učinak intenzivnije promocije urbanističkog prostornog identiteta Ličkog Osika na interes ispitanika za posjet mjestu značajno je povezan $s$ njihovim iskustvom boravka u Ličkom Osiku ( $\mathrm{p}=0,002 ; \mathrm{Phi}=0,28)$. Među ispitanicima koji nisu posjetili Lički Osik znatno je veći udio onih koji smatraju da bi intenzivnija promocija urbanističkog prostornog identiteta Ličkog Osika pojačala njihov interes za posjet mjestu (78\% prema 58\%). Kod 21\% onih koji su već posjetili Lički Osik intenzivnija promocija urbanističkog prostornog identiteta ne bi povećala interes za posjet mjestu.

Usporedba mišljenja rezidenata i nerezidenata ukazala je na značajne razlike u percepciji prostorno-urbanog identiteta Ličkog Osika $(\mathrm{p}<0,001 ;$ Phi $=0,24)$. Među rezidentima je znatno veći udio onih koji smatraju da Lički Osik ima prepoznatljiv prostorno-urbani identitet (56\% prema 41\%). U tu svrhu bitno je istražiti stavove stanovnika prema prostornom identitetu, njegovim obilježjima i odrazima na život, ali i razvojnim perspektivama koje počivaju na njemu. Iz izloženog anketnog istraživanja u najvećoj mjeri proizlazi da su stanovnici svjesni prostorno-urbanog identiteta, no ne doživljavaju ga kao dio svog osobnog identiteta, a time ga ni ne smatraju značajnim turističkim potencijalom. S druge strane nepoznavanje je dijelom i odraz nedostatka edukacije o vrijednostima lokalnog prostornog identiteta, a to je nepoznavanje u suprotnosti s glavnim pojmovima (možemo čak reći i očekivanjima) nerezidenata (potencijalnih posjetitelja).

\section{Zaključak}

Istraživanje je pokazalo da iako Lički Osik još nije formalno prepoznat i zaštićen kao kulturno dobro, njegov urbanističko-arhitektonski sklop ima prepoznatljive činitelje lokalnog prostornog identiteta, koji se očituju u karakteristikama: rijetkosti (jer je jedinstveno takvo naselje na prostoru Hrvatske), izvornosti (jer sadrži originalne elemente u odnosu na društveno-tehničke kriterije) te ambijentalne i prostorne prepoznatljivosti (jer pokazuje sklad organiziranog naselja te kvalitetu u urbanoj strukturi kao i u odnosu na krajolik).

Primjer Ličkog Osika pokazuje kako se i u teškim vremenima, sa skromnim sredstvima i jednostavnim arhitektonskim jezikom može realizirati urbani sklop na postulatima modernističkog urbanog humanizma - od planiranih funkcija do realiziranih javnih prostora i sadržaja. 
Promijenjene društveno-ekonomske okolnosti dovele su do promišljanja o novom korištenju prostora, odnosno prilagodbi postojeće prostorne strukture novim potrebama, što ujedno predstavlja i moguće opasnosti za prepoznatljiv prostorni integritet jer nema planova razvoja baziranih, između ostalog, na naslijeđu. Do sada je specifično urbanističko-arhitektonsko naslijeđe Ličkog Osika relativno slabo istraživano i njegove su kvalitete relativno slabo poznate lokalnom stanovništvu, ali i donositeljima odluka o budućem prostornom razvoju.

Lički Osik predstavlja primjer maloga planiranog industrijskog grada na prostoru Hrvatske te se postavlja pitanje zaštite njegova urbanističko-arhitektonskog naslijeđa, koja bi trebala zaštititi osnovne elemente urbanističke strukture istovremeno ostavljajući dovoljno prostora za nužne preinake, preispitivanje pojedinih programa i prilagodbe novim uvjetima. Za sada je samo gospodarska kriza sačuvala postojeću prostornu strukturu grada od znatnijih intervencija. Svaka nova intervencija dovodi do mogućih opasnosti za prostorni integritet cjeline.

Iz ankete o percepciji prostornog identiteta Ličkog Osika proizlazi da se urbanistička slika Ličkog Osika izrazito dualno percipira (pozitivno i negativno). U pozitivnim elementima ponajviše je definirana planskom izgradnjom, a u negativnim nepostojanjem radnih mjesta i industrijske proizvodnje. S obzirom da potencijali Ličkog Osika za daljnji razvoj nisu jednoliko percipirani od svih ispitanih dionika, u promišljanju budućnosti naselja mogu se pretpostaviti tri moguća scenarija razvoja: a) postupno funkcionalno odumiranje naselja, b) nastavak sadašnjeg stanja uz spori rast opterećen brojnim izazovima te c) revitalizacija temeljem integralnog razvoja inovativnog gospodarstva, što uključuje i razvoj turizma.

Iz provedene ankete utvrđeno je kako je daljnji razvoj Ličkog Osika potrebno bazirati na promišljanju njegovih vlastitih vrijednosti i na potencijalima njegovog vlastitog prostora. U vidu zaštite te njenog korištenja kao daljnjeg potencijala u turizmu baziranom na industrijskom naslijeđu bitno je istaknuti i važnost edukacije o osobitostima grada, koja bi lokalnom stanovništvo mogla pomoći u usvajanju urbanističke slike Ličkog Osika kao dijela njihovog osobnog identiteta.

Industrijsko graditeljsko naslijeđe kao dio turističke resursne osnove ne odnosi se samo na velike industrijske pogone ili proizvode već i na male planirane gradove. Planirana industrijska naselja - osobito ona koja su izvedena u kratkom vremenu i stoga predstavljaju svojevrsni spomenik promišljanju prostora određenog vremena sve više postaju predmet interesa turista. Iako se radi o specifičnim, vrlo uskim nišama turističke potražnje, činjenica je da u slučajevima malih gradova to i odgovara mogućim kapacitetima takvih sredina, bez opasnosti da se pređu granice održivosti.

Iako u Hrvatskoj pojam industrijskog, a uz to još i socijalističkog grada još uvijek većinom nosi negativne konotacije, možda je upravo Lički Osik - kao jedan od posljednjih planiranih industrijskih gradova u Hrvatskoj - primjer na kojem je moguće primijeniti recentna europska iskustva i temeljiti njegov identitet (uključivo i turistički identitet) upravo na činjenici da se radi o oglednom primjeru industrijskoga socijalističkog grada, smjelo planiranog, u segmentima nedovršenog, ali i s nespornim 
kvalitetama nove urbane cjeline koja je trebala biti podloga i iskaz stvaranja novog, drukčijeg društva.

\section{Literatura}

1. Andrusz, G.; Harloe M.; Szelenyi, I. (Eds.) (1996). Cities after Socialism - Urban and Regional Change and Conflict in Post-Socialist Societies. Oxford - Cambridge: Blackwell.

2. Apolitika (2013). Arbitektonske politike Republike Hrvatske, Nacionalne smjernice za vrsnoću kulture građenja. Zagreb: Ministarstvo graditeljstva i prostornog uređenja.

3. Bamert, M.; Ströbele, M.; Buchecker, M. (2016). Ramshackle farmhouses, useless old stables, or irreplaceable cultural heritage? Local inhabitants' perspectives on future uses of the Walser built heritage. Land Use Policy, 55: 21-129.

4. Byrd, E. T. (2007). Stakeholders in Sustainable Tourism Development and their Roles: Applying Stakeholder Theory to Sustainable Tourism Development. Tourism Review, 62 (2): 6-13.

5. Catrina, S. (2015). Local Heritage Interpretation by Private "Cultural Agents" from Maramureú. Procedia - Social and Behavioral Sciences, 188: 174 - 180.

6. Curić, Z. (1993.) Prometnogeografsko značenje luke Ploče. Geografski Glasnik, 55: 191-202.

7. Di Battista, A. and Čelik, M. (2012). New cities in Slovenia 1945-1960, in: Mrduljaš, M. and Kulić, V. (Eds.). Unfinished modernisations, between utopia and pragmatism. Zagreb: UHA/CCA, 246-259.

8. Državni zavod za statistiku. Popis stanovništva 2011., (http://www.dzs.hr/).

9. Faro konvencija (2005). Zakon o potvrđivanju okvirne konvencije Vijeća Europe o vrijednosti kulturne baštine za društvo, "Narodne novine - međunarodni ugovori" br. 5. od 09.05.2007.

10. Föhl, A. (2014). Endless possibilities - wide reuse of industrial buildings as a cultural and economical asset- forty years of industrial archeology, in: Palinić. N.; Rotim Malvić, J.; Đekić, V. (Eds.). Rijeka i industrijsko graditeljsko naslijeđel baština arbitekture i građevinarstva - zbornik radova. Rijeka: Protorpedo.

11. Fry, G. L. A. (2001). Multifunctional landscapes - towards transdisciplinary. Landscape and Urban Planning, 57: 159-168.

12. Holt-Jensen, A. and Raagmaa, G. (2010). Restitution of agricultural land in Estonia: Consequences for landscape development and production. Norsk Geografisk Tidsskrift, 64 (3): 129-141.

13. Ifko, S. (2014). Industrial Architectual Heritage - re-avaluating research parametars for more authentic preservation approaches. Arbitektura \& Urbanizmus, 48 (3-4): 317-155.

14. Kadioglu, Y. (2011). Land use and major issues of planning in city of Trabzon. Procedia Social and Behavioral Sciences, 19: 354-362.

15. Klempa M.; Bujok, P.; Jelínek, J.; Porzer, M.; Pavluš, J. (2015.) Reconstruction of former industrial complexes and their utilisation in tourism - case study. Tourism, 63 (2): 247-258. 
16. Kranjčević, J. and Božić, N. (2012). Is There a Future for Planned new Towns of the 20th Century? The Case of Lički Osik, Croatia, in: Hysa, A. (Ed.). First International Conference on Architecture and Urban Design (1-ICAUD). Tirana: Epoka University, 385-403.

17. Kranjčević, J. i Božić, N. (2013). Lički Osik-planirani industrijski grad. Zagreb: Hrvatska sekcija ECOVAST i Institut za turizam.

18. Lončar., J i Cvitanović, M. (2012). (Post)socijalizam i okoliš: promjena kulturnoga krajobraza Pridravske nizine Osijeka u posljednjih pedeset godina. Sociologija i prostor, 94 (3): 327-343.

19. Loures L. and Panagopoulos T. (2007). From derelict industrial areas towards multifunctional landscapes and urban renaissance. WSEAS Transactions on Environment and Development, 3 (8): 177-184.

20. Marković, I. i Fuerst-Bjeliš, B. (2015). Prostorni identitet kao pokretačka snaga razvoja turizma: komparativna analiza regija Bjelovara i Čakovca. Hrvatski geografski glasnik, 77/1: 71-88.

21. McDonald, S.; Malys, N. and Maliene, V. (2009.) Urban regeneration for sustainable communities: A case study. Ukio Technologinis ir Ekonominis Vystymas, 15 (1): 49-59.

22. Melluma, A. (1994.) Metamorphoses of Latvian landscapes during fifty years of Soviet rule. GeoJorunal, 33 (1): 55-62.

23. Miletić, G. M.; Uršić, S. i Mišetić, A. (2011). Socijalna održivost i procesi urbane transformacije u hrvatskim malim gradovima: pogled odozgo, u: Božić, N. i Dumbović Bilušić, B. (Ur.). Zbornik radova međunarodnog znanstvenostručnog skupa Modeli upravljanja procesima obnove i razvoja povijesnih gradova, Primjer Ivanić-Grada: Mogućnosti revitalizacije obnove starog Ivanića. Zagreb: Hrvatska sekcija ECOVAST-a.

24. Molnarova, B. (2014). The classification of values of industrial heritage in Slovakia, u: Palinić. N.; Rotim Malvić, J. i Đekić, V. (Ur.). Rijeka i industrijsko graditeljsko naslijeđe/baština arbitekture i građevinarstva - zbornik radova. Rijeka: Protorpedo.

25. Ostroški, Lj. (2011). Model diferencijacije urbanih, ruralnih i prijelaznih naselja Republici Hrvatskoj, Metodološke upute 67/2011. Zagreb: Državni zavod za statistiku.

26. Pavlović, B. (1956). Problem reprojekta naselja Lički Osik. Lički kalendar, 1956: 23-26.

27. Pejnović, D. (2010). Geografske osnove identiteta i njegovo značenje za održivi razvoj geoprostora, u: Spahić, M. (Ur.). Zbornik radova drugog kongresa geografa Bosne i Hercegovine. Sarajevo: Geografsko društvo BiH.

28. Pličanić, M. i Pozder, N. (2014). Prepoznavanje autentičnosti „Ugljenog grada“ u $\mathrm{BiH}$ kao potencijalnog industrijskig naslijeđa u kontekstu njegove regeneracije - studija slučaja: grad Vareš, u: Palinić. N.; Rotim Malvić, J i Đekić, V. (Ur.). Rijeka i industrijsko graditeljsko naslijeđe/baština arbitekture i građevinarstva zbornik radova. Rijeka: Protorpedo.

29. Pličanić, M. i Turkušić, E. (2014). Radničko naselje moderne s „kućom za neoženjene radnike" u Varešu - prilog istraživanju arhitekture Juraja Neidhardta, u: Palinić. N.; Rotim Malvić, J. i Đekić, V. (Ur.). Rijeka i industrijsko graditeljsko naslijeđe/baština arbitekture i građevinarstva - zbornik radova. Rijeka: Protorpedo. 
30. Proshansky, H. (1978). The City and Self-Identity. Environment and Behavior, 10 (2): 147-169.

31. Ramirez-de-la-Piscina Armendariz, E. (2014). Former closed cities in the soviet Baltic sea region / landscape: Confronting a dissonant heritage in Estonia and Latvia. Master Thesis in Landscape Architecture. Tartu: Estonian University of Life Sciences.

32. Seferagić, D. (2013.) Razvoj sociologije grada i prostora u Hrvatskoj. Sociologija i prostor, 196 (2): 281-290.

33. Shirakia, H.; Ashinaa, S.; Kameyamaa, Y.; Hashimotob, S.; Fujitaa, T. (2015). Analysis of optimal locations for power stations and their impact on industrial symbiosis planning under transition toward low-carbon power sector in Japan. Journal of Cleaner Production, 114: 81-94.

34. Slaev, A. and Nikiforov, I. (2013). Factors of Urban Sprawl in Bulgaria. Spatium International Review, 29: 22-29.

35. Smajić, E. i Trožić, E. (2014). Industrijsko graditeljsko naslijeđe Sarajeva, u: Palinić, N.; Rotim Malvić, J. i Đekić, V. (Ur.). Rijeka i industrijsko graditeljsko naslijeđel baština arhitekture i građevinarstva - zbornik radova. Rijeka: Protorpedo.

36. Stobbelaar, D. J. and Hendriks, K. (2004). Reading the identity of Place. Multiple Landscape Conference, Wageningen: Wageningen University: 1-12.

37. Šerić, M., Talijančić, J. and Perišić, M. (2011). Identity of national heritage in function of specialised tourist offer of Croatia. Analele Stiintifice ale Universitatii "Alexandru Ioan Cuza" din Iasi, 58: 327-338.

38. United Nations (2012). Millennium Development, Goals Report 2012. New York: United Nations.

39. Văetişi, Ş. (2011). The Material Culture of the Postsocialist City. A Success/Failure Perspective. Martor, 16: 81-95.

40. Vranić, D. (2014). The Resistance of Architecture to Political Regime(s): the Case of Novi Zagreb. Sociologija i prostor, 198 (1): 41-67.

\section{Popis slika:}

Slika 1. Lički Osik sredinom 1950-ih godina. Pogled na glavni trg.

Izvor: Državni arhiv Gospić

Slika 2. Planirani gradovi građeni nakon Drugog svjetskog rata: Travnik (Bosna i Hercegovina) i Velenje (Slovenija)

Izvor: Stare razglednice oko 1960-te

Slika 3. Regulacijski plan Ličkog Osika iz 1949. godine

Izvor: časopis „Arhitektura“ vol. 9., br. 5-6

Slika 4. Prostorni smještaj Ličkog Osika u odnosu na postojeće naselje i radnu zonu. Izvor: autori 
Slika 5. Funkcionalna shema Ličkog Osika - dispozicija javnih sadržaja i javnih prostora

Izvor: autori

Slika 6. Hotel na glavnom trgu Ličkog Osika

Izvor: Monografija građevinskog poduzeća „Tempo“, 1978.

Slika 7. Tipovi stambenih zgrada iz rane faze izgradnje Ličkog Osika (1950-te godine)

Izvor: autori

Slika 8. Sađeno zaštitno zelenilo uz prometnicu koja vodi do radne zone Izvor: autori

Slika 9. Hotel na glavnom trgu nakon Domovinskog rata (fotografije iz 2011. godine) Izvor: autori

Slika 10. Skladni ambijent stanovanja u zelenilu u Ličkom Osiku - fotografija iz 2011. godine

Izvor: autori

Slika 11. Osnovni pozitivni elementi prostorno-urbanističke slike Ličkog Osika Izvor: rad autora temeljem ankete 2015. godine

Slika 12. Osnovni negativni elementi prostorno-urbanističke slike Ličkog Osika Izvor: rad autora temeljem ankete 2015. godine 
Jasenka Kranjčević

Institute for Tourism, Zagreb, Croatia

e-mail: jasenka.kranjcevic@iztzg.hr

Izidora Marković

Institute for Tourism, Zagreb, Croatia

e-mail: izidora.markovic@iztzg.hr

Nikša Božić

Croatian Section ECOVAST, Zagreb, Croatia

e-mail:niksa.bozic@ecovast.hr

\title{
Lički Osik - Urban and Architectural Heritage as Tourism Development Potential
}

\begin{abstract}
One of the main issues facing towns in post-industrial societies is how to stimulate the new socio-economic and cultural development after the collapse of industry This is an issue of particular importance in areas which, after the industrial collapse, struggle with numerous economic and social challenges. In Croatia, Lički Osik is such an example of a planned industrial city built immediately after World War II.

In the paper the local identity of Lički Osik is determined through elements of urban and architectural heritage. Given the fact that spatial identity depends on personal perception, a survey was conducted among residents and non-residents in order to investigate the perceptions of spatial identity and determine the development potential of cultural heritage, in particular urban and architectural heritage of Lički Osik, for the development of cultural tourism.
\end{abstract}

Key words: Lički Osik, urban and architectural heritage, tourist attractions, perception of identity, heritage in function of tourism. 